University of Rhode Island

DigitalCommons@URI

Civil \& Environmental Engineering Faculty

Publications

Civil \& Environmental Engineering

2020

\title{
Potential Implications of Acid Mine Drainage and Wastewater Cotreatment on Solids Handling: A Review
}

Charles D. Spellman Jr.

University of Rhode Island

Travis L. Tasker

Joseph E. Goodwill

University of Rhode Island, goodwill@uri.edu

William H.J. Strosnider

Follow this and additional works at: https://digitalcommons.uri.edu/cve_facpubs

The University of Rhode Island Faculty have made this article openly available.

Please let us know how Open Access to this research benefits you.

This is a pre-publication author manuscript of the final, published article.

Terms of Use

This article is made available under the terms and conditions applicable towards Open Access

Policy Articles, as set forth in our Terms of Use.

Citation/Publisher Attribution

Spellman, C. D., Jr., Tasker, T. L., Goodwill, J. E., \& Strosnider, W. H.J. (2020). Potential Implications of Acid Mine Drainage and Wastewater Cotreatment on Solids Handling: A Review. Journal of Environmental

Engineering, 146(11). 03120010. doi: 10.1061/(ASCE)EE.1943-7870.0001814

Available at: https://doi.org/10.1061/(ASCE)EE.1943-7870.0001814

This Article is brought to you for free and open access by the Civil \& Environmental Engineering at DigitalCommons@URI. It has been accepted for inclusion in Civil \& Environmental Engineering Faculty Publications by an authorized administrator of DigitalCommons@URI. For more information, please contact digitalcommonsgroup@uri.edu. 


\section{Potential Implications of Acid Mine Drainage and Wastewater Co-treatment on Solids Handling: A Review}

Charles D. Spellman Jr${ }^{1}$, Travis L. Tasker Ph.D. ${ }^{2}$, Joseph E. Goodwill Ph.D. P.E. ${ }^{3}$, William H.J. Strosnider Ph.D. ${ }^{4}$

${ }^{1}$ Dept. of Civil and Environmental Engineering, University of Rhode Island, Kingston, RI, 02881.Email: cspellman@uri.edu

${ }^{2}$ Dept. of Environmental Engineering, Saint Francis University, Loretto, PA 15940. Email: ttasker@francis.edu

$11{ }^{3}$ Dept. of Civil and Environmental Engineering, University of Rhode Island, Kingston, RI, 02881

12 (Corresponding author).Email: goodwill@uri.edu

134 Belle W. Baruch Marine Field Laboratory, University of South Carolina, Georgetown, SC

14 29440.Email: bill@baruch.sc.edu

\section{Abstract}

17 Acid mine drainage (AMD) is a persistent and extensive source of water pollution and ecological

18 degradation. Co-treating municipal wastewater (MWW) with AMD using existing infrastructure

19 at conventional wastewater treatment plants (WWTPs) may serve as a potential option for AMD

20 abatement. However, commonly elevated iron and aluminum concentrations and low $\mathrm{pH}$ of

21 AMD could negatively impact various processes at a WWTP. The focus of this mini-review was

22 to determine how co-treating MWW with AMD could impact the solids handling processes at a

23 WWTP. While no studies have explored the solids that could be generated during co-treatment in

24 a WWTP, there are numerous articles that separately discuss the solids generated during AMD or

25 MWW treatment. Reviewing this literature revealed that iron and aluminum, common metals in

26 AMD, are already present in MWW sludge and typically benefit most solids handling processes.

27 The addition of AMD would elevate iron and aluminum concentration but would likely result in

28 improved sludge dewatering, removal of odor-causing compounds during processing, and a

29 decreased bioavailability of trace metals and water-soluble $\mathrm{P}$ in land applications. This review

30 concludes that co-treating MWW with moderate-to-low volumes $(<50 \%)$ of AMD within

31 WWTPs will have minimal impact, and likely improve, solids handling processes.

33 Keywords: Acid Mine Drainage; Wastewater treatment; Co-treatment; Iron; Waste management;

\section{Sewage Sludge.}




\section{Introduction}

Global industrialization has brought about a plethora of legacy pollution issues, including acid mine drainage (AMD). AMD is created when sulfide-containing minerals, such as pyrite $\left(\mathrm{FeS}_{2}\right)$, are exposed to oxygen and water after mining or other types of land disturbance (Younger et al. 2002). The resulting discharges often have elevated acidity (some coal drainages may be net neutral), elevated sulfate and iron (Fe) concentrations from the oxidation of sulfide rock, and a variety of trace metals [e.g., aluminum (Al), manganese $(\mathrm{Mn})$, copper $(\mathrm{Cu})$, zinc $(\mathrm{Zn})$, arsenic $(\mathrm{As})$, and lead $(\mathrm{Pb})]$ from low $\mathrm{pH}$ driven dissolution of surrounding rocks (Evangelou and Zhang 1995; Jacobs et al. 2014; Strosnider et al. 2011; Younger et al. 2002). AMD abatement can be obtained by both passive (e.g. limestone dissolution, engineered wetlands) and active (e.g., chemical addition) treatment approaches (Hedin et al. 1994; Johnson and Hallberg 2005; Watzlaf et al. 2004). However, additional approaches can include co-treating

AMD with other wastes such as organic solid waste substrates, agricultural slurry, fracking flowback water, or municipal wastewater (MWW) (Chang et al. 2000; He et al. 2016; Hughes and Gray 2013a; McDevitt et al. 2020). Benefits of co-treating AMD with other wastewaters includes providing low cost AMD abatement, improving effluent quality from treatment systems, and mitigating AMD impacts on receiving bodies.

Co-treating MWW with AMD could enhance conventional waste water treatment plant (WWTP) processes, including improved colloid destabilization (i.e. coagulation) during metal hydrolysis (Metcalf \& Eddy et al. 2013), precipitative removal of biochemical oxygen demand (i.e. “enhanced coagulation”, Edzwald and Tobiason 1999), increased nutrient removal by phosphate adsorption onto metal hydroxides (Ruihua et al. 2011), and enhanced inactivation of fecal coliforms (Winfrey et al. 2010). Co-treatment may also offer opportunities for bioelectricity 
58 generation (Vélez-Pérez et al. 2020). Although successful co-treatment with AMD and MWW

59 has been noted primarily in passive systems (e.g. Johnson and Younger 2006; McCullough et al.

60 2008; Strosnider and Nairn 2010), effective co-treatment has also been demonstrated in more

61 conventional MWW treatment scenarios (Deng and Lin 2013; Ruihua et al. 2011; Wei et al.

62 2008). In a comprehensive bench scale examination of AMD and MWW co-treatment, Hughes

63 and Gray (2012, 2013a; b) demonstrated improved phosphate adsorption, metal (e.g., Fe and Al)

64 removal, decreased effluent chemical oxygen demand (COD) concentrations, and concluded that

65 co-treatment should not degrade activated sludge system performance. Although the literature

66 suggests that co-treating AMD and MWW within the existing infrastructure of WWTPs is

67 feasible, there are substantial research gaps prohibiting full-scale adaptation. One overlooked

68 factor is the impacts of AMD addition on a MWW facility's waste solids handling and

69 subsequent disposal processes.

70 Nearly all WWTP processes generate physical byproducts classified as "solids" that

71 require separate treatment and disposal. Solids, generalized as "sludge", encompasses pre-

72 treatment grit, sludge from primary sedimentation, wasted activated sludge, and filtration

73 backwash solids (Carnes and Eller 1972). Larger objects removed by screening (e.g. "rags")

74 which are typically directly landfilled will not be classified as solids in the scope of this review.

75 Solids treatment and disposal (i.e. "solids handling") is equally as intricate and important as

76 liquid-phase treatment. Solids may require pre-treatment such as chemical-conditioning,

77 thickening, and/or digestion which is traditionally followed by mechanical dewatering (filter

78 pressing, centrifugation, etc.) (Carnes and Eller 1972). Treated solids can either be landfilled,

79 incinerated, or conditioned for beneficial reuse. Conditioned solids for the purpose of land

80 application are defined as "biosolids." 
AMD strength (acidity, $\mathrm{pH}$, metal concentrations, etc.) can vary greatly with mine type

82 (coal versus hard rock drainage) and geographic location, meaning no two drainages are alike.

83 However, the authors suggest that co-treating MWW with AMD, in general, could result in

84 elevated concentrations of $\mathrm{Fe}$ and $\mathrm{Al}$ (found in most mine drainages) in solids generated during

85 MWW treatment. These elevated metal concentrations may impact facilities solids handling

86 processes. The primary objective of this review is to identify how certain AMD metals (i.e.,

87 elevated Fe and Al loads) from co-treatment with MWW may influence traditional WWTP solids

88 handling processes.

\section{Review Methodology}

This review identified relevant peer-reviewed research that highlight the impact of $\mathrm{Al}$ and

91 Fe on MWW solids handling processes. Releyant literature was identified through Google

92 Scholar searches and was extracted from bibliography sections in relevant textbooks. Keywords

93 that were used alone and in various combinations to find literature included "activated sludge",

94 "trace metals", “acid mine drainage", "iron", "aluminum", "metal hydroxides", and "sludge

95 handling." There was no bias towards certain publications and all works were reviewed equally.

96 The authors acknowledge the limited number of articles published within the last ten years, with

97 the majority being published prior to 2010. However, all cited studies were screened via the

98 Elsevier Scopus citation database (www.scopus.com) to ensure the cited information was the

99 most recent and relevant.

\section{Review Results}

It is not uncommon for metals, especially Fe, to appear in MWW solids in substantial

102 amounts. Typical concentrations of Fe range from 1 to $300 \mathrm{~g}$ per dry kilogram of MWW solids, 
103 with little information on Al or Mn (Environmental Protection Agency 2009). These metals are

104 of little concern for WWTPs as they are relatively unregulated as sludge constituents. Neither Fe

105 nor $\mathrm{Al}$ in solids is currently regulated as a pollutant for land application or landfilling (per U.S.

106 Code of Federal Regulations Title 40, Part 503); Fe and Al are not mentioned in any of these

107 regulations (as of March. 27, 2020) nor regulations for other countries (per European Union

108 Directive 86/278/EEC). Generally, increasing Fe and Al concentrations in a facility's secondary

109 treatment processes may have overall benefits for the WWTP. Elevated Fe and Al concentrations

110 in sludge have been correlated with lower COD concentrations in plant final effluents, likely by

111 coagulation mechanisms (Park et al. 2006). Improved effluent water quality is the primary aim

112 for a WWTP, but $\mathrm{Al}$ and Fe addition by co-treatment will likely benefit other MWW treatment

113 processes, such as solids handling. The benefits that could be provided by MWW co-treatment

114 with AMD are summarized in Table 1 and discussed in depth in the following text.

115

116 Conditioning and Dewatering

117 Introduction of increased Fe and Al concentrations from AMD could improve sludge

118 dewatering during co-treatment of MWW. Al and Fe salts that undergo hydrolysis are often used

119 for sludge conditioning and to improve coagulation of suspended particles (Davis and Edwards

120 2014; Novak 2006). The addition of these metal salts decreases raw sludge specific resistance to

121 filtration (SRF) and lowers the percent of "bound water" within the sludge, thus reducing the

122 time needed for dewatering (Katsiris and Kouzeli-Katsiri 1987). Yu et al. (2016) demonstrated a

123 negative curvilinear correlation between Fe(III) and sludge water (Fig. 1).

124 In comparison between $\mathrm{Fe}$ and $\mathrm{Al}$ coagulants, ferric $\mathrm{Fe}$ [Fe(III)] based coagulants remove

125 approximately double the bound water compared to those treated with Al [ $82 \%$ vs only $48 \%$ 
126 removal, respectively] (Katsiris and Kouzeli-Katsiri 1987). The decrease in bound water leads to

127 more efficient and cost-effective sludge dewatering. Therefore, increasing Fe(III) concentrations

128 by co-treating MWW and AMD may improve sludge settling and dewatering. It is also not

129 uncommon for drinking water utilities that use metal coagulants to send their Fe/Al-rich sludge

130 to a WWTP for disposal as an alternative to landfilling, as many drinking water facilities do not

131 operate an on-site sludge handling system. WWTPs accepting these sludges have generally

132 experienced no negative impacts on their treatment processes (Asada et al. 2010; Marguti et al. 133 2018).

134 The presence of Al in secondary MWW waste sludge has benefits that are similar to 135 those provided by $\mathrm{Fe} . \mathrm{Al}(\mathrm{OH})_{3}$ concentration was demonstrated to be inversely proportional to 136 the SRF, implying Al also improves sludge dewaterability (Hsu and Pipes 1973). Furthermore, 137 anaerobic digestion of Al-rich sludge before dewatering further improved dewaterability by 138 nearly two orders of magnitude. The Al particles act as "skeleton builders", significantly 139 strengthening the solids bulk structure and improving water movement out of the sludge (Lai and 140 Liu 2004). However, certain Al species or complexes can lead to variability in dewatering 141 performance. For example, polymerized forms (mixed with polymer) of hydrolyzed $\mathrm{Al}$ improve 142 sludge dewatering by allowing higher resistance to compression (Cao et al. 2016). This, 143 however, only holds implications for co-treatment scenarios where polymers are also added 144 during dewatering.

145 Co-treating MWW with AMD may also serve as a low-cost alternative to implementation 146 of an advanced oxidation process (AOP). AOP is a technique that can be used at WWTPs to 147 generate numerous radicals that improve oxidation processes and sludge conditioning (Glaze et 148 al. 1987; Neyens and Baeyens 2003). AOP can occur by mixing ferrous Fe [Fe(II)] with 
149 hydrogen peroxide, facilitating a Fenton reaction that generates hydroxyl radicals and Fe(III).

150 Co-treatment with Fe-rich AMD could replace a Fenton AOP and retain comparable dewatering

151 efficiency. Yu et al. (2016) directly compared sludge dewatering characteristics with addition of

152 Fe in the form of either Fe(II), Fe(III), or a variation of the Fenton AOP process. The

153 experiments mixed sludge and Fe (always $48 \mathrm{mg} \mathrm{Fe} / \mathrm{g}$ sludge) in a conditioning tank followed by

154 pumping the mixture to a pressure-controlled feed tank, and then dewatering the mixture via a

155 laboratory diaphragm filter press. The addition of Fe improved dewatering to some degree in all

156 cases when compared to control raw sludge (Fig. 2).

157 Although Yu et al. noted that Fenton reactions achieved the best performance, Fe(III)-

158 alone without an AOP still significantly improved sludge water content. Increased Fe(III) content

159 decreases the sludge cake water content by up to $15 \%$ compared to raw sludge (RS), suggesting

160 that adding AMD through co-treatment could improve sludge processing. Conversely, Fe(II)

161 yielded little to no improvement over the RS. An AMD discharge with an increased Fe(II)

162 fraction would require significant oxidation for enhanced sludge processing. Although the Fe(II)

163 results are noteworthy, it is of minimal concern for co-treatment adaptability as it will be rapidly

164 oxidized to Fe(III) in a WWTPs aeration basin. However, this could be of concern for WWTPs

165 co-treating MWW with AMD that store sludge in an anaerobic system with long detention times

166 where Fe reduction would likely occur (Rasmussen et al. 1994). The stability of Al in the +3

167 oxidation state could be more suitable during anaerobic storage and processing (Park et al. 2006).

168 Co-treating MWW with AMD will also impact the $\mathrm{pH}$ of sludge and further influence the

169 performance of the solids handling system. Sludge $\mathrm{pH}$ is inversely proportional to its

170 dewaterability, with an optimum dewatering $\mathrm{pH}$ of 2.5 for both centrifugal or filtration

171 dewatering (Chen et al. 2001). However, operating at extremely acidic pH values is likely not 
172 feasible due to elevated corrosion risks and slower oxidation rates of odor-causing compounds

173 (Nielsen et al. 2006). Yet sludge flocs have been shown to still maintain structural stability over

174 a pH range of 4.5 to 9.5 (Liao et al. 2002) while also maintaining SRF between pH 3 and 7, with

175 less desirable SRF at higher $\mathrm{pH}$ values (Raynaud et al. 2012). Over a pH range of 3.2 to 9.1,

176 lower $\mathrm{pH}$ values also correlated with a lower sludge shear sensitivity (i.e. stronger flocs)

177 (Mikkelsen et al. 1996). The improved sludge dewaterability over a lower $\mathrm{pH}$ range is attributed 178 to positively charged ions from acid compounds (e.g. $\mathrm{H}^{+}, \mathrm{Fe}^{+3}$, etc.) neutralizing the sludge

179 particles surface charges. The neutralization leads to improved aggregation and a particle size

180 distribution more conducive to dewatering (Karr and Keinath 1978). At a higher pH, the size

181 distribution shifts to high concentrations of smaller particles that fill voids, trap water, and clog

182 filtration pores reducing overall bound water movement (Raynaud et al. 2012). Although lower

$183 \mathrm{pH}$ may improve dewaterability, dewatered sludge will require amendments (i.e., lime, etc.) to

184 obtain the $\mathrm{pH}$ necessary for post-dewatering processes [e.g., minimum $\mathrm{pH}$ for biosolids land 185 application is 12 (Doyle 1967)].

\section{Odor Control and Anaerobic Processes}

Managing odor is a common nuisance and cost burden at many WWTPs (Dague 1972).

189 Fe from co-treatment may help mitigate odor at WWTPs and could present positive economic

190 benefits for the immediate community by increasing surrounding property values by up to $15 \%$

191 (Lebrero et al. 2011). Divalent metal species in AMD, including unoxidized Fe(II), can scavenge

192 and react with the primary odor-causing compound $\mathrm{H}_{2} \mathrm{~S}$ to form insoluble metal sulfide

193 complexes which are non-odorous (Johnson and Hallberg 2005). This suggests that the addition

194 of Fe(II) in mostly anaerobic settings (e.g. AMD added after aeration) would assist in decreasing 
195 odor causing compounds during solids processing. Oxidized Fe in aerobic co-treatment systems

196 will also enhance odor reduction. The addition of zero-valent $\mathrm{Fe}(\mathrm{Fe} 0)$ nanoparticles at various

197 doses to MWW sludge demonstrated improved oxidation of $\mathrm{H}_{2} \mathrm{~S}$ to form Fe sulfides and

198 increased the final biosolids nutrient bioaccessibility (Li et al. 2007). The resultant Fe-sulfides

199 further reacted with $\mathrm{H}_{2} \mathrm{~S}$ to form Fe polysulfides without the need for additional Fe input.

200 Although the aforementioned study utilized $\mathrm{Fe} 0$, only the core of the nanoparticles contained $\mathrm{Fe} 0$

201 while the shell was oxidized and consisted of hydroxides/oxyhydroxides. These hydrolyzed Fe

202 compounds are similar to those that would form after oxidation of AMD Fe.

203 Al addition also improves the overall anaerobic sludge digestion processes. Biogas often

204 contains volatile sulfur compounds (e.g. $\mathrm{H}_{2} \mathrm{~S}, \mathrm{CH}_{3} \mathrm{SH}, \mathrm{CS}_{2}$ ) that cause nuisance odors and

205 corrosion issues. Dosing Al can remove high percentages of these dangerous sulfur compounds

206 from biogas while maintaining consistent digester performance (Akgul et al. 2017). Additionally,

207 the total volume of biogas generated would be expected to decrease (Hsu and Pipes 1973) likely

208 resulting from significant removal of volatile compounds. Furthermore, the same study showed a

209 noticeable decrease in digester coliform counts as well as improved dewaterability after

210 digestion. All of the aforementioned improvements could equate to significant cost savings for a

211 WWTP, in addition to benefits from reduced odors. These results suggest that co-treatment with

212 Al-rich AMD (which is relatively rare) would be most advantageous at a WWTP operating an

213 anaerobic digestion system, due to the valance-stability of A1.

214

215 Biosolids Composition and Land Application

216 Although MWW solids may contain 1 to $300 \mathrm{~g}$ of Fe per dry kilogram of solids

217 (Environmental Protection Agency 2009), only a handful of studies have examined the 
218 relationship between $\mathrm{Fe}$ and $\mathrm{Al}$ content in water and resulting biosolids $\mathrm{Fe}$ and $\mathrm{Al}$ content. As

219 previously discussed, there are minimal regulatory standards for common AMD metals in

220 biosolids. However, trace metals and metalloids (e.g. $\mathrm{Pb}, \mathrm{Hg}$, and $\mathrm{As}$ ) in biosolids can have

221 environmental and human health implications if they bioaccumulate or leach after land

222 application (Arulrajah et al. 2011). Both As and $\mathrm{Hg}$ have frequently been investigated for their

223 role in biosolids toxicity during land use. AMD from the eastern part of the United States rarely

224 has As and Hg concentrations above drinking water standards (Herlihy et al. 1990), but elevated

225 concentrations of various metals and metalloids of concern (e.g., As, $\mathrm{Cd}, \mathrm{Pb})$ can be found in

226 other geographic locations which would have negative implications for co-treatment feasibility

227 (Cheng et al. 2009; Rytuba 2000; Strosnider et al. 2011). Decreasing the bioavailability of trace

228 metals and metalloids in soil is important when considering if biosolids can be applied to land.

229 Fig. 3 demonstrates the difference in bioavailability of $\mathrm{Pb}$ during a field study when $99 \% \mathrm{Fe}-$

230 powder was added to biosolids compost (109 $\mathrm{g} \mathrm{Fe} / \mathrm{kg}$ ) and mixed with soil (Brown et al. 2012).

231 Experimental analysis showed that $75 \%$ of the Fe in the amended biosolids was Fe(III), similar

232 to what might be expected of co-treatment biosolids.

233 Although Fe amended biosolids decreased the bioavailability of $\mathrm{Pb}$ (Fig. 3) there was

234 significantly less impact on As bioavailability (Brown et al., 2012). The increased retention of

235 toxic compounds by elevated-Fe biosolids during soil application renders amended biosolids

236 marketable not just as compost, but also as remediation substrate for sequestering trace metals

237 (e.g. Pb) in soils (Farfel et al. 2005). It is important to note that the substantial concentration of

238 Fe added $(>80 \mathrm{~g} / \mathrm{kg})$ in the Brown et al. experiment would only be expected under co-treatment

239 with a high ratio of Fe-rich AMD. This Fe concentration is likely orders of magnitude higher

240 than what a typical AMD discharge [AMD Fe varies $1 \mu \mathrm{g} / \mathrm{L}$ to $>600 \mathrm{mg} / \mathrm{L}$ (Johnson 2003; 
241 Strosnider et al. 2011; Younger et al. 2002) and 0.2-70 mg/L Fe for coal mine drainage

242 (Strosnider et al. 2020)] might contribute in a co-treatment system. In these situations, solids

243 trace metal bioavailability would likely not be improved as demonstrated in the Brown et al. low

$244 \mathrm{Fe}(5 \mathrm{~g} \mathrm{Fe} / \mathrm{kg})$ experiments. These results imply that decreased toxic compound concentrations

245 could only be expected during co-treatment on a case by case basis as a function of AMD and

246 MWW influent Fe concentrations and system Fe removal capabilities.

247 Both Fe and Al may benefit agricultural land application of biosolids. AMD metals have

248 demonstrated potential related to improving soil phosphorus (P) availability. Adler and Sibrell

249 (2003) showed that additions of neutralized AMD "flocs" to high-P soil (20 g floc / kg soil)

250 could sequester roughly $70 \%$ of water-extractable P. A similar result was noted in a larger scale

251 study, where application of manure mixed with AMD treatment residuals to a large parcel of

252 farmland decreased the water-soluble P content (Sibrell et al. 2015). Similarly, mixing biosolids

253 with Al-rich water treatment alum sludge improved agricultural crop yields in traditional potting

254 soil by retaining higher concentrations of P at both laboratory (60 days) and greenhouse (105

255 days) scales (Mahdy et al. 2009). Furthermore, the application of Al-hydroxides (1 to 4\% w/w)

256 in the aforementioned study also decreased the total nutrient loading in greenhouse runoff. The

257 reduction of soluble $\mathrm{P}$ in biosolids amended with Al-rich water treatment sludge is caused by the

258 formation and precipitation of $\mathrm{Al} / \mathrm{Fe}-\mathrm{P}$ complexes or $\mathrm{P}$ adsorption unto hydroxides (Huang et al.

259 2007). Commercially available Fe(III)-rich biosolids have varying results on agricultural use,

260 demonstrating improved growth size of oranges but no impact on pear growth (Pérez-Sanz et al.

261 2002). However, most studies examining agricultural Fe-rich biosolids applications

262 demonstrated non-negative yet neutral impacts on fruit growth. There is a strong potential for

263 AMD co-treatment biosolids to support localized agriculture. Co-treatment could reduce 
264 demands for artificial fertilizers and potentially decrease nutrient loading on waterways without

265 negatively impacting agriculture processes.

266

267 Incineration Considerations

268 Co-treatment has the potential to impact sludge incineration operations. The

269 aforementioned inverse relationship between $\mathrm{Al}$ and $\mathrm{Fe}$ content and sludge bound water would

270 also improve the combustibility of the dewatered sludge, reducing stress on incinerator

271 processes. Furthermore, the resulting ash would have increased amounts of extractable P (Farfel

272 et al. 2005). Ash generated by incinerating sludge from co-treated MWW with AMD could

273 improve nutrient recovery and be viewed as a beneficial reuse product. Due to increasing global

274 stress on P demand, WWTP processes have long been a point of focus as a source of potential P

275 recovery and recycling (Farfel et al. 2005; Ottosen et al. 2013). Ash product produced from a co-

276 treating incineration facility with a high extractable P could alleviate local P demand. Incinerated

277 sludge ash can contain up to 10\% P by mass (Donatello and Cheeseman 2013) and the amount of

278 P that is recoverable is directly proportional to ash value. Sludge ash can successfully be applied

279 to land as a fertilizer (Bierman and Rosen 1994). Therefore, this beneficial use ash also carries

280 economic incentives, as it is now a product to boost revenue rather than a waste. Furthermore,

281 the extractable P-rich ash is significantly less dense than a dried and stabilized sludge making it

282 more economically viable to transport.

283 There are also disadvantages to be considered for incineration facilities. Depending on

284 the water chemistry of the AMD, the ash could contain higher weight-percentages of toxic trace

285 metals (e.g. As and Pb). Ash containing $>100 \mathrm{mg} / \mathrm{kg}$ of $\mathrm{Pb}$ would be considered a hazardous

286 waste and could not be disposed of in a traditional municipal landfill. $\mathrm{Pb}$ concentrations in 
287 municipal landfills can be indirectly associated with a variety of health issues for neighboring 288 communities (Kim and Williams 2017), and remains a liability for the generator. Furthermore,

289 As is a primary contaminant in landfill leachates (Pinel-Raffaitin et al. 2006), and a landfill

290 would likely not accept As-containing wastes due to the potential costs required for As treatment 291 after leaching.

\section{Conclusions}

From a solids handling perspective, co-treating MWW with AMD could provide

294 numerous benefits for a WWTP. The metals common to AMD (e.g., Fe, Al) are already present

295 in conventional MWW sludges, and additional loads from co-treatment would not result in

296 concentrations above those seen in some facilities. Current regulations indicate that sludges with

297 high concentrations of these metals can be easily disposed in landfills or land applied. When Fe

298 and $\mathrm{Al}$ concentrations are elevated, they may provide additional benefits that could make co-

299 treating MWW with AMD more economically viable. For example, elevated Fe and Al can

300 improve sludge dewatering, potentially lowering operating costs. The $\mathrm{Al}$ in these sludges can

301 also decrease concentrations of odor causing compounds that are often challenging to control at

302 WWTPs. Other opportunities might exist to use the biosolids or incinerated sludges (i.e., ash)

303 from co-treating MWW with AMD for soil remediation or agricultural amendments (e.g.

304 immobilizing trace metals in contaminated soils). While the findings of this review suggest that 305 there are potential benefits from co-treating MWW with AMD, many questions remain to be 306 answered before full-scale implementation. Further research into potential impacts from other 307 common AMD metals $(\mathrm{Cu}, \mathrm{Mn}, \mathrm{Zn}$, etc.) is needed. Future work should also include laboratory 308 scale studies to investigate the outcomes of this review in various co-treatment scenarios (e.g. 309 dewatering, digestion systems, incineration, and land application). 


\section{Data Availability Statement}

312 No data, models, or code were generated or used during the study

\section{Acknowledgements}

315 This review was primarily funded by the Foundation for Pennsylvania Watersheds (Alexandria,

316 PA). Any views expressed in this work belong solely to the authors not the funding agency. The

317 authors also acknowledge Matthew McClimans (Mattabassett District Water Pollution Control

318 facility) for input on operations of solids handling \& disposal systems. This is contribution

319 number 1882 for the Belle W. Baruch Institute for Marine and Coastal Sciences.

321 References

322 Adler, P. R., and Sibrell, P. L. (2003). "Sequestration of Phosphorus by Acid Mine Drainage

323 Floc.” Journal of Environmental Quality, 32(3), 1122-1129.

324 Akgul, D., Abbott, T., and Eskicioglu, C. (2017). “Assessing iron and aluminum-based

325 coagulants for odour and pathogen reductions in sludge digesters and enhanced digestate

326 dewaterability." Science of the Total Environment, Elsevier B.V., 598, 881-888.

327 Arulrajah, A., Disfani, M. M., Suthagaran, V., and Imteaz, M. (2011). "Select chemical and 328 engineering properties of wastewater biosolids.” Waste Management, Elsevier Ltd, 31(12), $329 \quad 2522-2526$.

330 Asada, L. N., Sundefeld, G. C., Alvarez, C. R., Filho, S. S. F., and Piveli, R. P. (2010). "Water 331 Treatment Plant Sludge Discharge to Wastewater Treatment Works: Effects on the 332 Operation of Upflow Anaerobic Sludge Blanket Reactor and Activated Sludge Systems.” 
Water Environment Research, 82(5), 392-400.

334 Bierman, P. M., and Rosen, C. J. (1994). "Phosphate and Trace Metal Availability from Sewage335 Sludge Incinerator Ash.” Journal of Environmental Quality, 23(4), 822-830.

336 Brown, S. L., Clausen, I., Chappell, M. A., Scheckel, K. G., Newville, M., and Hettiarachchi, G.

337 M. (2012). "High-Iron Biosolids Compost-Induced Changes in Lead and Arsenic

338 Speciation and Bioaccessibility in Co-contaminated Soils." Journal of Environment Quality, $339 \quad 41(5), 1612$.

340 Cao, B., Zhang, W., Wang, Q., Huang, Y., Meng, C., and Wang, D. (2016). "Wastewater sludge

341 dewaterability enhancement using hydroxyl aluminum conditioning: Role of aluminum

342 speciation.” Water Research, Elsevier Ltd, 105, 615-624.

343 Carnes, B. A., and Eller, J. M. (1972). “Characterization of Wastewater Solids.” Journal (Water

$344 \quad$ Pollution Control Federation), 44(8), 1498-1517.

345 Chang, I. S., Shin, P. K., and Kim, B. H. (2000). "Biological treatment of acid mine drainage

346 under sulphate-reducing conditions with solid waste materials as substrate.” Water

347 Research, Pergamon, 34(4), 1269-1277.

348 Chen, Y., Yang, H., and Gu, G. (2001). "Effect of acid and surfactant treatment on activated

349 sludge dewatering and settling." Water Research, 35(11), 2615-2620.

350 Cheng, H., Hu, Y., Luo, J., Xu, B., and Zhao, J. (2009). “Geochemical processes controlling fate 351 and transport of arsenic in acid mine drainage (AMD) and natural systems." Journal of 352 Hazardous Materials.

353 Dague, R. R. (1972). "Fundamentals of Odor Control.” Journal (Water Pollution Control

354 Federation), Water Environment Federation, 44(4), 583-594.

355 Davis, C. C., and Edwards, M. A. (2014). “Coagulation with hydrolyzing metal salts: 
Mechanisms and water quality impacts." Critical Reviews in Environmental Science and Technology, 44(4), 303-347.

Deng, D., and Lin, L.-S. (2013). "Two-stage combined treatment of acid mine drainage and municipal wastewater." Water Science and Technology, 67(5), 1000-1007.

Donatello, S., and Cheeseman, C. R. (2013). "Recycling and recovery routes for incinerated sewage sludge ash (ISSA): A review.” Waste Management, Elsevier Ltd, 33(11), 2328-

Doyle, C. B. (1967). "Effectiveness of high pH for destruction of pathogens in raw sludge filter 2340. cake.” Journal (Water Pollution Control Federation), Wiley, 39(8), 1403-1409.

Edzwald, J. K., and Tobiason, J. E. (1999). "Enhanced coagulation: US requirements and a broader view." Water Science and Technology, IAWQ, 40(9), 63-70.

Environmental Protection Agency. (2009). Targeted National Sewage Sludge Survey Sampling and Analysis Technical Report. EPA-822-R-08-016, Washington, DC 20460.

Evangelou, V. P. (Bill), and Zhang, Y. L. (1995). “A review: Pyrite oxidation mechanisms and acid mine drainage prevention." Critical Reviews in Environmental Science and Technology, 25(2), 141-199.

Farfel, M. R., Orlova, A. O., Chaney, R. L., Lees, P. S. J., Rohde, C., and Ashley, P. J. (2005). amendment and grass seeding in urban yards." Science of the Total Environment, 340(1-3), $81-95$.

Glaze, W. H., Kang, J.-W. W., and Chapin, D. H. (1987). "The chemistry of water treatment processes involving ozone, hydrogen peroxide and ultraviolet radiation." Ozone: Science \& Engineering, 9(4), 335-352. 
He, C., Zhang, T., and Vidic, R. D. (2016). "Co-treatment of abandoned mine drainage and Marcellus Shale flowback water for use in hydraulic fracturing." Water Research, Pergamon, 104(5), 425-431.

Hedin, R. S., Nairn, R. W., and Kleinmann, R. L. P. (1994). Passive treatment of coal mine drainage. Infromation Circular 9389.

Herlihy, A. T., Kaufmann, P. R., Mitch, M. E., and Brown, D. D. (1990). "Regional estimates of acid mine drainage impact on streams in the mid-atlantic and Southeastern United States." Water, Air, and Soil Pollution, 50(1-2), 91-107.

Hsu, D. Y., and Pipes, W. O. (1973). “Aluminum Hydroxide Effects on Wastewater Treatment Processes." Journal of the Water Pollution Control Federation, 45(4), 681-697.

Huang, X. L., Chen, Y., and Shenker, M. (2007). "Solid phosphorus phase in aluminum- and iron-treated biosolids." Journal of Environmental Quality, 36(2), 549-556.

Hughes, T. A., and Gray, N. F. (2012). "Acute and Chronic Toxicity of Acid Mine Drainage to the Activated Sludge Process." Mine Water and the Environment, 31(1), 40-52.

Hughes, T. A., and Gray, N. F. (2013a). "Co-treatment of acid mine drainage with municipal wastewater: Performance evaluation." Environmental Science and Pollution Research, 20(11), 7863-7877.

Hughes, T. A., and Gray, N. F. (2013b). "Removal of Metals and Acidity from Acid Mine Drainage Using Municipal Wastewater and Activated Sludge." Mine Water and the Environment, 32(3), 170-184.

Jacobs, J. A., Lehr, J. H., and Testa, S. M. (2014). Acid Mine Drainage, Rock Drainage, and Acid Sulfate Soils: Causes, Assessment, Prediction, Prevention, and Remediation. Acid Mine Drainage, Rock Drainage, and Acid Sulfate Soils: Causes, Assessment, Prediction, 
402

403

404

405

406

407

408

409

410

411

412

413

414

415

416

417

418

419

420

421

422

423

424

\section{Prevention, and Remediation.}

Johnson, D. B. (2003). “Chemical and microbiological characteristics of mineral spoils and draiangewaters at abandoned coal and metal mines." Water, Air, and Soil Pollution: Focus, $3(1), 47-66$.

Johnson, D. B., and Hallberg, K. B. (2005). “Acid mine drainage remediation options: a review." Science of The Total Environment, 338(1-2), 3-14.

Johnson, K. L., and Younger, P. L. (2006). "The co-treatment of sewage and mine waters in aerobic wetlands." Engineering Geology, 85(1-2), 53-61.

Karr, P. R., and Keinath, T. M. (1978). "Influence of particle size on sludge dewaterability." Journal (Water Pollution Control Federation), 50(8), 1911-1930.

Katsiris, N., and Kouzeli-Katsiri, A. (1987). "Bound water content of biological sludges in relation to filtration and dewatering." Water Research, 21(11), 1319-1327.

Kim, M. A., and Williams, K. A. (2017). "Lead Levels in Landfill Areas and Childhood Exposure: An Integrative Review." Public Health Nursing, 34(1), 87-97.

Lai, J. Y., and Liu, J. C. (2004). "Co-conditioning and dewatering of alum sludge and waste activated sludge." Water Science and Technology, 50(9), 41-48.

Lebrero, R., Bouchy, L., Stuetz, R., and Muñoz, R. (2011). “Odor Assessment and Management in Wastewater Treatment Plants: A Review." Critical Reviews in Environmental Science and Technology, 41(10), 915-950.

Li, X. Q., Brown, D. G., and Zhang, W. X. (2007). "Stabilization of biosolids with nanoscale zero-valent iron (nZVI)." Journal of Nanoparticle Research, 9(2), 233-243.

Liao, B. Q., Allen, D. G., Leppard, G. G., Droppo, I. G., and Liss, S. N. (2002). “Interparticle Interactions Affecting the Stability of Sludge Flocs." Journal of Colloid and Interface 
425

426

427

428

429

430

431

432

433

434

435

436

437

438

439

440

441

442

443

444

445

446

447

Science, 249(2), 372-380.

Mahdy, A. M., Elkhatib, E. A., Fathi, N. O., and Lin, Z.-Q. (2009). "Effects of Co-Application of Biosolids and Water Treatment Residuals on Corn Growth and Bioavailable Phosphorus and Aluminum in Alkaline Soils in Egypt.” Journal of Environment Quality, 38(4), 1501.

Marguti, A. L., Ferreira Filho, S. S., and Piveli, R. P. (2018). "Full-scale effects of addition of sludge from water treatment stations into processes of sewage treatment by conventional activated sludge." Journal of Environmental Management, Elsevier, 215, 283-293.

McCullough, C. D., Lund, M. A., and May, J. M. (2008). "Field-scale demonstration of the potential for sewage to remediate acidic mine waters." Mine Water and the Environment, 27(1), 31-39.

McDevitt, B., Cavazza, M., Beam, R., Cavazza, E., Burgos, W. D., Li, L., and Warner, N. R. (2020). "Maximum Removal Efficiency of Barium, Strontium, Radium, and Sulfate with Optimum AMD-Marcellus Flowback Mixing Ratios for Beneficial Use in the Northern Appalachian Basin.” Environmental Science \& Technology, 54(8), 4829-4839.

Metcalf \& Eddy, I., Tchobanoglous, G., Stensel, H. D., Tsuchihashi, R., and Burton, F. (2013). Wastewater Engineering: Treatment and Resource Recovery. McGraw-Hill Education, New York, NY.

Mikkelsen, L. H., Gotfredsen, A. K., Agerbæk, M. L., Nielsen, P. H., and Keiding, K. (1996). "Effects of colloidal stability on clarification and dewatering of activated sludge." Water Science and Technology, 34(3-4), 449-457.

Neyens, E., and Baeyens, J. (2003). “A review of classic Fenton’s peroxidation as an advanced oxidation technique." Journal of Hazardous Materials, 98(1-3), 33-50.

Nielsen, A. H., Vollertsen, J., and Hvitved-Jacobsen, T. (2006). "Kinetics and Stoichiometry of 
448

449

450

451

452

453

454

455

456

457

458

459

460

461

462

463

464

465

466

467

468

469

470

Aerobic Sulfide Oxidation in Wastewater from Sewers-Effects of $\mathrm{pH}$ and Temperature.” Water Environment Research, 78(3), 275-283.

Novak, J. T. (2006). “Dewatering of Sewage Sludge.” Drying Technology, 24(10), 1257-1262.

Ottosen, L. M., Kirkelund, G. M., and Jensen, P. E. (2013). “Extracting phosphorous from incinerated sewage sludge ash rich in iron or aluminum." Chemosphere, Elsevier Ltd, 91(7), 963-969.

Park, C., Muller, C. D., Abu-Orf, M. M., and Novak, J. T. (2006). “The Effect of Wastewater Cations on Activated Sludge Characteristics: Effects of Aluminum and Iron in Floc.” Water Environment Research, 78(1), 31-40.

Pérez-Sanz, A., Álvarez-Férnandez, A., Casero, T., Legaz, F., and José Lucena, J. (2002). “Fe enriched biosolids as fertilizers for orange and peach trees grown in field conditions." Plant and Soil, 241(1), 145-153.

Pinel-Raffaitin, P., Ponthieu, M., Le Hecho, I., Amouroux, D., Mazeas, L., Donard, O. F. X., and Potin-Gautier, M. (2006). "Evaluation of analytical strategies for the determination of metal concentrations to assess landfill leachate contamination." Journal of Environmental Monitoring, 8(10), 1069-1077.

Rasmussen, H., Bruus, J. H., Keiding, K., and Nielsen, P. H. (1994). “Observations on dewaterability and physical, chemical and microbiological changes in anaerobically stored activated sludge from a nutrient removal plant." Water Research, 28(2), 417-425.

Raynaud, M., Vaxelaire, J., Olivier, J., Dieudé-Fauvel, E., and Baudez, J.-C. (2012).

“Compression dewatering of municipal activated sludge: Effects of salt and pH.” Water Research, 46(14), 4448-4456.

Ruihua, L., Lin, Z., Tao, T., and Bo, L. (2011). "Phosphorus removal performance of acid mine 
471

472

473

474

475

476

477

478

479

480

481

482

483

484

485

486

487

488

489

490

491

492

493

drainage from wastewater.” Journal of Hazardous Materials, Elsevier B.V., 190(1-3), 669676.

Rytuba, J. J. (2000). "Mercury mine drainage and processes that control its environmental impact." Science of the Total Environment.

Sibrell, P. L., Penn, C. J., and Hedin, R. S. (2015). “Reducing Soluble Phosphorus in Dairy Effluents through Application of Mine Drainage Residuals.” Communications in Soil Science and Plant Analysis, Taylor \& Francis, 46(5), 545-563.

Strosnider, W. H. J., Hugo, J., Shepherd, N. L., Holzbauer-Schweitzer, B. K., Hervé-Fernández, P., Wolkersdorfer, C., and Nairn, R. W. (2020). "A Snapshot of Coal Mine Drainage Discharge Limits for Conductivity, Sulfate, and Manganese across the Developed World." Mine Water and the Environment, Springer Berlin Heidelberg.

Strosnider, W. H. J., López, F. S. L., and Nairn, R. W. (2011). “Acid mine drainage at Cerro Rico de Potosí I: Unabated high-strength discharges reflect a five century legacy of mining." Environmental Earth Sciences, 64(4), 899-910.

Strosnider, W. H. J., and Nairn, R. W. (2010). "Effective passive treatment of high-strength acid mine drainage and raw municipal wastewater in Potosí, Bolivia using simple mutual incubations and limestone.” Journal of Geochemical Exploration, Elsevier B.V., 105(1-2), $34-42$.

Vélez-Pérez, L. S., Ramirez-Nava, J., Hernández-Flores, G., Talavera-Mendoza, O., EscamillaAlvarado, C., Poggi-Varaldo, H. M., Solorza-Feria, O., and López-Díaz, J. A. (2020). "Industrial acid mine drainage and municipal wastewater co-treatment by dual-chamber microbial fuel cells." International Journal of Hydrogen Energy, 45(26), 13757-13766.

Watzlaf, G. R. G., Schroeder, K. K. T., Kleinmann, R. L. P., Kairies, C. L., and Nairn, R. W. 
(2004). The Passive Treatment of Coal Mine Drainage. DOE/NETL-2004/1202, Pittsburgh, PA.

Wei, X., Viadero, R. C., and Bhojappa, S. (2008). "Phosphorus removal by acid mine drainage sludge from secondary effluents of municipal wastewater treatment plants." Water Research, 42(13), 3275-3284.

499 Winfrey, B. K., Strosnider, W. H. J., Nairn, R. W., and Strevett, K. A. (2010). "Highly effective reduction of fecal indicator bacteria counts in an ecologically engineered municipal wastewater and acid mine drainage passive co-treatment system.” Ecological Engineering,

$502 \quad$ Elsevier B.V., 36(12), 1620-1626.

503 Younger, P. L., Banwart, S. A., and Hedin, R. S. (2002). Mine Water. Environmental Pollution, $504 \quad$ Springer Netherlands, Dordrecht.

505 Yu, W., Yang, J., Shi, Y., Song, J., Shi, Y., Xiao, J., Li, C., Xu, X., He, S., Liang, S., Wu, X., and $\mathrm{Hu}, \mathrm{J}$. (2016). "Roles of iron species and $\mathrm{pH}$ optimization on sewage sludge conditioning with Fenton's reagent and lime.” Water Research, 95, 124-133. 
510 Table 1. Summary of key improvements on solids handling from co-treatment.

\begin{tabular}{|c|c|}
\hline Potential benefits of co-treating MWW with AMD & Relevant Citation \\
\hline $\begin{array}{l}\text { AMD addition would elevate iron concentrations above a } \\
\text { facility's current levels, but resulting concentrations would } \\
\text { likely not exceed those already commonly observed in } \\
\text { typical MWW sludges ( } 1 \text { to } 300 \mathrm{~g} \text { Fe per dry kg) }\end{array}$ & EPA, 2009 \\
\hline $\begin{array}{l}\text { Iron and aluminum concentrations are correlated with a } \\
\text { decrease in COD concentrations }\end{array}$ & Park et al., 2006 \\
\hline $\begin{array}{l}\text { Increases in iron concentration generally reduces sludge } \\
\text { water content }\end{array}$ & $\begin{array}{l}\text { Katsiris and Kouzeli-Katsiri, } \\
\text { 1987; Yu et al. (2016) }\end{array}$ \\
\hline Aluminum decreases sludge specific resistance to filtration & Hsu and Pipes, 1973 \\
\hline $\begin{array}{l}\text { WWTPs co-treating MWW with AMD containing high } \\
\text { iron concentrations have ability to easily adapt to a Fenton } \\
\text { AOP }\end{array}$ & Yuet al. (2016) \\
\hline Decrease in $\mathrm{pH}$ improves dewaterability & $\begin{array}{l}\text { Raynaud et al 2012; } \\
\text { Karr and Keinath } 1978\end{array}$ \\
\hline $\begin{array}{l}\text { AMD metals may precipitate nuisance odor-causing } \\
\text { compounds }\end{array}$ & Johnson and Hallberg, 2005 \\
\hline $\begin{array}{l}\text { Aluminum addition is advantageous for WWTPs with } \\
\text { anaerobic digestion }\end{array}$ & $\begin{array}{l}\text { Akgul et al., 2017; Hsu \& Pipes, } \\
1973\end{array}$ \\
\hline $\begin{array}{l}\text { Iron can decrease bioavailability and mobility of trace } \\
\text { metals in land application }\end{array}$ & $\begin{array}{l}\text { Farfel et al., 2005; Brown et al. } \\
2012\end{array}$ \\
\hline $\begin{array}{l}\text { Iron-rich biosolids decrease water-soluble phosphorus } \\
\text { content when added to fertilizer }\end{array}$ & $\begin{array}{l}\text { Adler and Sibrell 2003; Farfel et } \\
\text { al., 2005; Sibrell et al., } 2015\end{array}$ \\
\hline $\begin{array}{l}\text { Incinerated sludge may be rich in phosphorus and used for } \\
\text { land application }\end{array}$ & $\begin{array}{l}\text { Farfel et al., 2005; Donatello \& } \\
\text { Cheeseman, } 2013\end{array}$ \\
\hline
\end{tabular}

